\title{
EFFECT OF MIXING BANANA PEELS WITH FRISH CATTLE MANURE ON BIOGAS PRODUCTION
}

\author{
M. A. Rashwan *
}

ABSTRACT

Egypt is an agricultural country and has a big potential of biogas generation from different types of wastes. Producing of biogas from agricultural wastes gives new and clean energy and good organic fertilizer as a method to protect environment from pollution by wastes. The digestion of banana peels mixed with cow dung for biogas production at laboratory scale was the subject of this investigation. Laboratory experiments were conducted to evaluate the biogas production from mixing banana peels fruits with fresh cattle manure in order to explore their potential application in biogas production. The study was carried out at a control temperature of $35 \pm 2^{\circ} \mathrm{C}$ for a period of 57 days with a total solid concentration of $8 \%$ in each reactor. The biogas and methane produced were collected by water displacement method. In the current work, four reactors were used: $A, B, C$ and D contains $0,20,40$ and $60 \%$ banana peels (by weight) mixed with fresh cattle manure respectively. The experiments run out in anaerobic system under control of temperature. The results showed that mixing banana peels ratio of $40 \%$ increase biogas production but increasing the ratio to $60 \%$ or more cause decreasing in biogas production.

\section{INTRODUCTION}

The main energy reservoirs of the world consist of fossil fuels like petroleum products, natural gas. These fossil fuels are not fulfilling the world energy demand but also creating environmental problems like greenhouse gases (NCAR, 2008). Also the rising of fossil oil potentially diminishing supplies, attendant pollution problems associated with petroleum and allied products. Therefore, the world is going to face a serious problem of energy scarcity after 100 years. On the other hand the problem of agricultural wastes becomes very obvious and aggregated after the harvest of summer crops.

*Assist. Prof. Agric. and Biosystems Eng. Dept., Fac. of Agric. (El-Shatby), Alexandria University. Egypt. 
That is because the farmer is in a rush to cultivate his land therefore getting rid of the wastes usually by burning causing harmful effects on the environment. In addition, storing these wastes in the field after compacting may make it suitable environment for reproduction and growth of pests and pathogens that will attack new crops. Therefore, utilization of agriculture wastes in any other environmentally friendly way is very important. Shaban and Omaima, (2010), addition of the agricultural wastes can be utilized by animal feed production, compost production or utilizing of these wastes in produce biogas. Producing of biogas from agricultural wastes by anaerobic digestion (AD) gives a new and clean source of energy and good organic fertilizer as a method to protect environment from pollution by wastes. Khalid et al., (2010) indicated that, bananas are grown in more than hundred countries, mostly in the developing world where they represent an important staple food. Banana is an important fruit crops, staple food and cash crop in Egypt, due its great economic importance as well as nutritional value and high availability throughout the year. Emmanuel et al., (2014) said that, bananas generate huge waste quantities, currently underutilized and discarded causing detrimental impact to the environment. Muhammed et al., (2009) compared the amount of methane produced from different fractions of banana (stem, peel, and fruit) through anaerobic batch digestion assays at $37{ }^{\circ} \mathrm{C}$ for a period of 35 days, they found that, the stem, peel and fruit fractions represented $0.84 \%, 17.71 \%$ and $81.46 \%$ of the total methane production potential of the whole banana with specific methane yield of $0.256,0.322$, and $0.367 \mathrm{~m}^{3} / \mathrm{kg}$ volatile solids respectively. Latika et al., (2012), reported that the banana peel can be converted into glucose which can be used as feedstock to produce ethanol by fermentation and distillation. Furthermore, ethanol by fermentation offers a more favorable trade balance, increased energy security, and a major new crop for a depressed agricultural economy. Mohapatra et al., (2010) reported that, banana peels have been found to contain lignin (6$12 \%)$, pectin (10-21\%), cellulose (7.6-9.6\%) and hemicelluloses (6.49.4\%). Effectively utilize banana wastes for bio-methane production, a promising pre-treatment method must be applied to these materials prior to their anaerobic digestion. Pre-treatment can be mechanical, biological, physicochemical or a combination of these methods. Biological pre- 
treatment of lignocelluloses substrates includes the use of white-rot fungi, pre-composting, hydrolytic bacteria and commercial enzymes. Drying and milling pre-treatments have been reported to improve the subsequent $\mathrm{AD}$ by $5 \%$ compared to the untreated. Muhammad et al., (2009), reported that, the banana waste is a concentrated source of putrid organic waste, ideal for anaerobic digestion to produce energy while fermentation products can serve as fertilizer with high nutritional value, as well as a valuable energy source in form of biogas. Channeling these peels in to the production of biogas is an efficient way of waste management. So that the object of this work is to make use of banana peels as an agricultural wastes in the production of biogas as a source of clean energy instead of discarded or burned, leading to contamination of the environment.

\section{MATERIALS AND METHODS}

\section{Collection and preparation of banana peels:}

The chemical analysis of banana peels indicated that, they contain lignin (6-12\%), pectin (10-21\%), cellulose (7.6-9.6\%) and hemicelluloses (6.49.4\%) (Mohapatra et al., 2010). Banana peels were collected from the local markets in Alexandria city. They cut into small pieces $(0.5-1 \mathrm{~cm})$, and washed with tap water several times to remove any external dirt. They were air dried to remove the free water (Figure 1). After that they dried into oven for 24 hours at $105^{\circ} \mathrm{C}$. The dried peels grinded into powder $(0.5-1 \mathrm{~mm})$ and kept in an air tied bottle prior to the experiments as shown in Figure 2. The physical and chemical composition of the materials (peel mix) were evaluated before and after digestion using standard procedures (AOAC, 1990) as shown in Table 1. The dried banana peels after those were mixed with cattle manure with a ratio of 20 , 40 and $60 \%$ by weight.
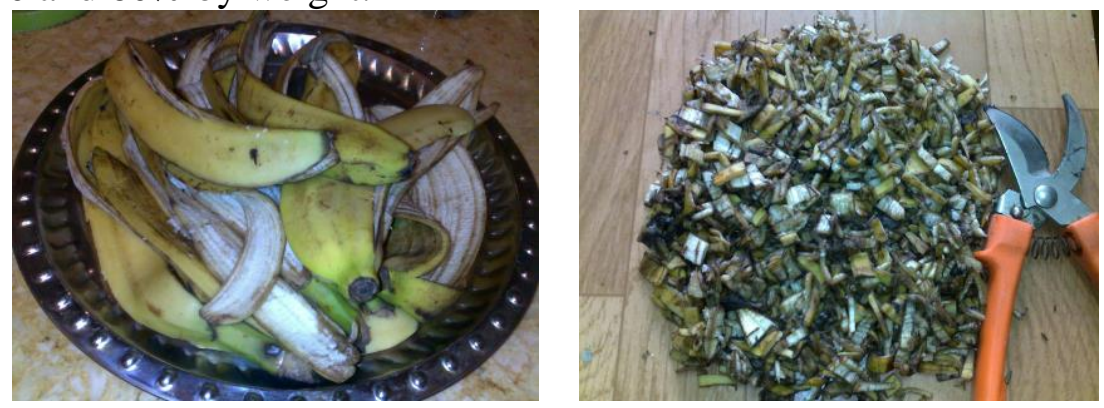

Fig. (1): Banana peels before and after cutting and air drying 


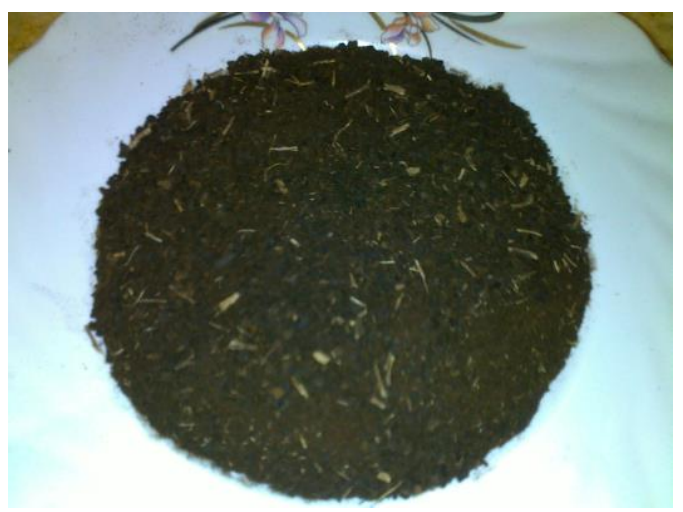

Fig. (2): Banana peels after grinded into powder

Table 1: physical-chemical analysis of different mixtures before and after digestion

\begin{tabular}{lcccccccc}
\hline \multirow{2}{*}{ Parameter } & \multicolumn{2}{c}{$\begin{array}{c}\text { Reactor A } \\
\text { Control }\end{array}$} & \multicolumn{2}{c}{$\begin{array}{c}\text { Reactor B } \\
20 \%\end{array}$} & \multicolumn{2}{c}{$\begin{array}{c}\text { Reactor C } \\
40 \%\end{array}$} & \multicolumn{2}{c}{$\begin{array}{c}\text { Reactor D } \\
60 \%\end{array}$} \\
\cline { 2 - 9 } & before & after & before & after & before & after & before & after \\
\hline pH & 7.26 & 7.02 & 7.15 & 6.95 & 7.32 & 7.01 & 7.44 & 6.53 \\
Reactor temp. & 34.5 & 34.7 & 35 & 34.9 & 35.1 & 35 & 34.9 & 35.2 \\
Moisture cont. & 96 & 92 & 94 & 89 & 91 & 87 & 88 & 86 \\
Total solids & 8.5 & 11.5 & 9 & 11 & 8.7 & 10.2 & 9.5 & 10.5 \\
Volatile solids & $\mathbf{8 8 . 2}$ & $\mathbf{8 4 . 8}$ & $\mathbf{8 5 . 2}$ & $\mathbf{8 2 . 4}$ & 89.7 & 86.1 & 87.8 & 86.3 \\
Carbon cont. & 49 & 47.1 & 47.33 & 45.8 & 49.8 & 47.8 & 48.78 & 47.94 \\
Nitrogen cont. & 1.87 & 1.82 & 1.86 & 1.75 & 2.11 & 1.98 & 2.25 & 2.21 \\
C/N Ratio & 26.2 & 25.88 & 25.45 & 26.17 & 23.6 & 24.14 & 21.68 & 21.69 \\
\hline
\end{tabular}

2. Laboratory analysis:

Laboratory analysis before starting every experiment consisted of: cattle manure condition including $\mathbf{p H}$, moisture content $(\boldsymbol{M C})$, total solids $(\boldsymbol{T S})$, volatile solids (VS) and carbone to nitrogen ratio ( $\mathrm{C} / \mathbf{N}$ ratio). The measured values of the previous parameters are shown in Table (2).

\subsection{Moisture contents:}

Moisture contents $(\boldsymbol{M C})$ were determined in peels by using the laboratory oven. The samples were kept for about 2-3 hours in the oven at $110^{\circ} \mathrm{C}$. The procedure was adapted from the book "standard methods $21 \mathrm{st}$ edition". 


\subsection{Total solids:}

To determine the total solids (TS) an approximately $10 \mathrm{~g}$ was placed on a foil plate and dried to a constant weight at $105^{\circ} \mathrm{C}$.

Total Solids, \% = Final weight $(g) \times 100 /$ Initial weight $(g)$

\section{Volatile solids:}

Volatile solids (VS) were determined using Muffle furnace model 186A. The procedure was adapted from the book "standard methods $21 \mathrm{st}$ edition". The samples were kept in the furnace for about 45 minutes at $550^{\circ} \mathrm{C}$. The dried residue from total solids analysis was weighed and heated in a crucible for two hours at $500^{\circ} \mathrm{C}$ in a preheated furnace. After cooling the crucible and ash were weighed.

Volatile Solids, $\%=100-\left(\left(V_{3}-V_{1}\right) \times 100 /\left(V_{2}-V_{1}\right)\right)$

Where

$\boldsymbol{V}_{\mathbf{1}}=$ Weight of the crucible, $\boldsymbol{V}_{\mathbf{2}}=$ Weight of dry residue and crucible, $V_{\mathbf{3}}=$ Weight of ash and crucible (after cooling)

\subsection{Carbon to nitrogen ratio $(\mathrm{C} / \mathrm{N}$ ratio $)$}

FAO (1992), reported that, nitrogen present in the feedstock to provides an essential element for synthesis of amino acids, proteins and nucleic acids; and it is converted to ammonia which, as a strong base, neutralizes the volatile acids produced by fermentative bacteria. An overabundance of nitrogen in the substrate can lead to excessive ammonia formation, resulting in toxic effects. Thus, it is important that the proper amount of nitrogen be in the feedstock, to avoid either nutrient limitation (too little nitrogen) or ammonia toxicity (too much nitrogen).

The Nitrogen content was obtained in laboratory using Kjeldahl method while, carbon content of the feedstock was measured by considering the volatile solids content that was expressed as a percentage and the total carbon content were obtained from volatile solids data using an empirical equation as reported by Badger et al., (1979):

Carbon, $\%=V S(\%) / 1.8$

Hence, the carbon to nitrogen ratio for each treatment is calculated by dividing the carbon percentage by nitrogen percentage. 
Table 2: Characters of raw materials

\begin{tabular}{lccccc}
\hline Raw materials & MC\% & TS\% & VS\% & pH & C/N ratio \\
\hline Fresh banana peels & 68.15 & 31.85 & 89.4 & 6.5 & 25.5 \\
Fresh cattle manure & 82.13 & 17.87 & 88.2 & 7.48 & 26.2 \\
\hline
\end{tabular}

\section{Experimental design and setup:}

Anaerobic digestion was carried out in four glass reactors (2 liter each), as shown in Figure (3). The four reactors A, B, C, and D were put inside a glass box (water bath $35 \times 35 \times 25 \mathrm{~cm}$ ), which has heater, fan and thermostat. Each reactor connects with two glasses with soft pipes, the first glass full of water and the second one is empty to receive the water from the first glass which represents the gas quantity according to water displacement method. While the methane content was monitored by using water displacement method after passing the gas through $5 \% \mathrm{NaOH}$ solution to absorb the carbon dioxide (Veeken and Hamelers, 1999)

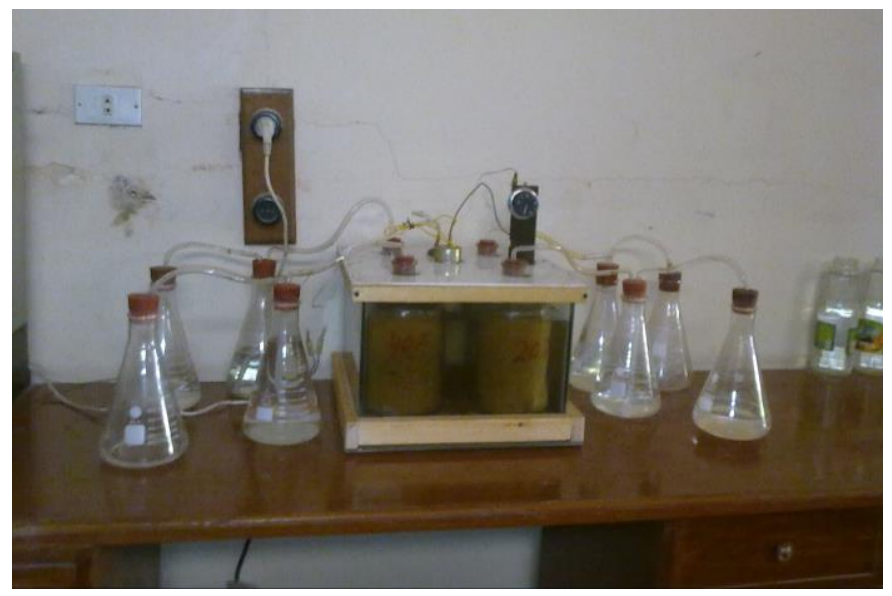

Fig. (3): A photo of the four reactors used in the experiment

The thermostat is fixed on the cover of the water bath and its pulp was put inside the water. The thermostat electrically connects to a heater and rotary fan. When water temperature decreases less than $35^{\circ} \mathrm{C}$ the heater and fan work until the temperature raise to $35^{\circ} \mathrm{C}$. The room temperature in this experiment was ranged between 18 and $28^{\circ} \mathrm{C}$ during the 57 days of the experiment. The materials used for this experiment were mixtures of grinded banana peels with cattle manure. 


\section{Reactors filling:}

A $300 \mathrm{~g}$ of cattle manure were diluted with tap water to get 8-10\% total solids content to get large amount of gas which agreed with most researchers (Budiyono, et al., 2010, Rashwan et al., 2012, Tsunatu D. et al., 2014). The initial moisture content of the manure was determined in three replicates by drying the samples in the oven at temperature of 105 ${ }^{\circ} \mathrm{C}$ for 24 hours. The moisture content was determined according to Eq. 4 in terms of wet basis (Anonymous 1998).

$$
M C(w . b .) \%=\frac{m_{w}}{m_{w}+m_{d}} \times 100
$$

Where:

$M C(\boldsymbol{w} . \boldsymbol{b}) \%=$. Moisture content of fresh manure (\%), $\boldsymbol{m}_{w}=$ mass of water in the manure $(\mathrm{g}), \boldsymbol{m}_{\boldsymbol{d}}=$ mass of dry matter in the manure $(\mathrm{g})$.

To achieve the desired moisture content for preparing the required total solid, an amount of water was added to the manure based on the following equation (Anonymous 1998):

$$
m_{w a}=\frac{\left(T S_{f}-T S_{S}\right)}{T S_{S}} \times m_{m}
$$

Where:

$\boldsymbol{T} \boldsymbol{S}_{\boldsymbol{f}}=$ initial total solid content of fresh manure (\%,w.b.), $\boldsymbol{T} \boldsymbol{S}_{\boldsymbol{s}}=$ desired total solid content of substrate manure (\%,w.b.), $\boldsymbol{m}_{\boldsymbol{m}}=$ initial mass of manure $(\mathrm{kg}), \boldsymbol{m}_{w a}=$ the mass of water added to manure $(\mathrm{kg})$.

Different weights of banana peels $0,60,120,180 \mathrm{~g}$ represent $0 \%, 20 \%$, $40 \%$, and $60 \%$ of cattle manure weight. They were mixed with cattle manure were used. The ratio of banana peels were $0 \%, 20 \%, 40 \%$, and $60 \%$ by weight for the reactors $\mathrm{A}, \mathrm{B}, \mathrm{C}$, and D respectively. Reactor A was chosen to be the control reactor. It was filled with only $300 \mathrm{~g}$ cattle manure diluted with water to get 8-10\% TS.

\section{Measuring quantity and quality of biogas}

The gas production is daily measured by water displacement method whereas the quality, which is the percentage of methane from the biogas, 
is estimated by the displacement of sodium hydroxide, with a process held one next to the other. A mount of gas volume produced in the digester was captured in a bottle filled with water, which was kept under pressure. The gas coming out of the digester is stored in the displaced bottle. Adding back the displaced water to the displacement bottle would push out the biogas stored before; and passing it through $5 \% \mathrm{NaOH}$ solution. The $\mathrm{CO}_{2}$ from the biogas would be retained in the solution whereas the methane would displace its equivalent volume of $\mathrm{NaOH}$. Collecting the displaced solution and measuring its volume using a measuring cylinder would give the volume of methane from the produced biogas (Veeken and Hamelers, 1999). Hence, it would be possible to estimate the percentage of methane in the biogas, using the following simple equation.

$$
\begin{array}{r}
\mathrm{CH}_{4}, \%=\frac{\text { Displaced } \mathrm{NaOH}}{\text { Displaced Water (volumeof biogas) }} \times 100 \\
\underline{\text { RESULTS AND DISCUSSION }}
\end{array}
$$

According to Table (1), it can be seen that, the results showed little variation between different reactors in $\mathrm{pH}$. The initial $\mathrm{pH}$ values of all reactors were ranged between 6.53 and 7.89 which agreed with various reports, and showed that the methanogenic bacteria are highly sensitive to $\mathrm{pH}$ and perform optimally in the $\mathrm{pH}$ range of 6.5 to 7.5 (Garba et al., 1996 and Uzodinma et al., 2008). The $\mathrm{C} / \mathrm{N}$ ratios of these agricultural wastes were within the optimum range of $\mathrm{C} / \mathrm{N}$ ratio for biogas production under mesophilic condition, which is 20-30:1 (Deublein and Steinhauser 2008). The results of the experiment which carried out for the 57 days retention time indicates that different volume of banana peels mix with fresh cattle manure affected the total biogas production. The biogas production is graphically shown in Figure (4), which indicates that, reactor A started the production on the $4^{\text {th }}$ day and reached to maximum value on the $29^{\text {th }}$ day $(\mathbf{8 0 0} \mathbf{~ m l})$. Reactor B started the production on the $3^{\text {rd }}$ day and reached to maximum value on the $6^{\text {th }}$ day $(\mathbf{8 7 0} \mathbf{~ m l})$. Reactor $C$ started the production on the $3^{\text {rd }}$ day and reached to maximum value on the $7^{\text {th }}$ day $(1250 \mathrm{ml})$. Reactor D started the production on the $4^{\text {th }}$ and reached to maximum value on the $17^{\text {th }}$ day $(\mathbf{8 5 0} \mathbf{~ m l})$. 


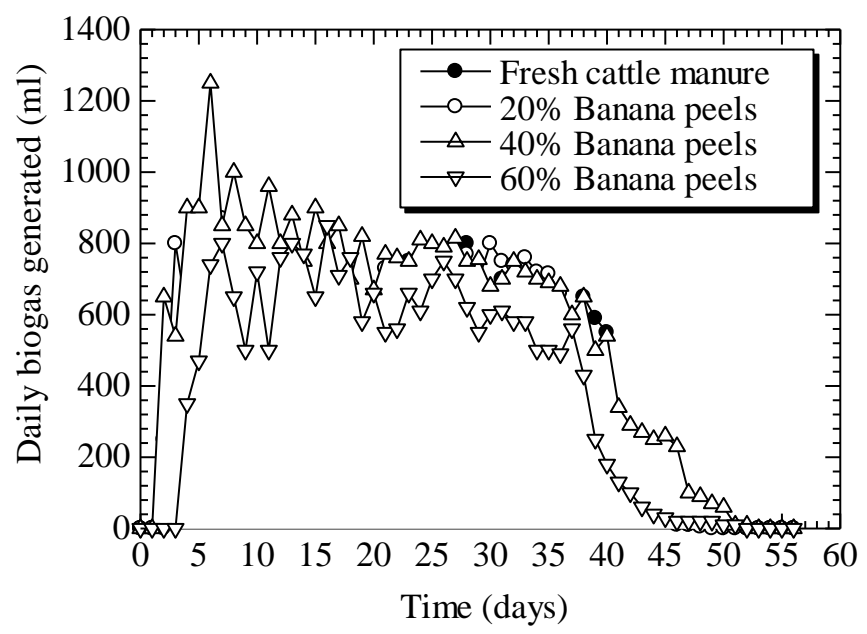

Fig. (4): Daily biogas production of different mixing banana peels with fresh cattle manure

Table 3. showed, the results of total biogas generated from all reactors. According to this table, production of reactor C ( $40 \%$ banana peels) gave the highest value of biogas $(\mathbf{3 2 0 6 1} \mathrm{ml})$ with average of $\mathbf{5 6 2 . 4 7} \mathrm{ml} /$ day. This high production value from reactor $\mathrm{C}$ was may attributed to the fact that a $\mathrm{pH}$ value between $\mathbf{7 . 3 2}$ and $\mathbf{7 . 0 1}$ is optimum for increased biogas and also may attributed to the balanced $\mathrm{C} / \mathrm{N}$ ratio. The yield of biogas from any substrate is highly dependent on the $\mathrm{C} / \mathrm{N}$ ratio of the material, concentration, $\mathrm{pH}$, temperature (Ponsá et al, 2008 \& NNFCC, 2011). In the case of $\mathrm{C} / \mathrm{N}$ ratio, 25 30:1 is optimum for biogas production (Maishanu et al, 1991). Reactor A produced the smallest value of biogas $(22525 \mathrm{ml})$ with average of $\mathbf{3 9 5 . 1 7} \mathrm{ml} / \mathrm{day}$. The low total biogas production from reactor D may be attributed to the general dominance of carbohydrates material in manure especially expense of protein and lipids which have been reported by (Hobson, 1983) to be the essential precursors for methane production, major constituent of biogas. Also dairy-cattle manure contains a refractory or non-biodegradable organic portion ranging from $38 \%$ to $63 \%$ of the total (Loehr, 1984).

Table 3. The total and mean volume of biogas generated

\begin{tabular}{lcccc}
\hline Parameter & $\begin{array}{c}\text { Reactor A } \\
\text { 0\% b. peel }\end{array}$ & $\begin{array}{c}\text { Reactor B } \\
\mathbf{2 0} \% \text { b. peel }\end{array}$ & $\begin{array}{c}\text { Reactor C } \\
\mathbf{4 0 \%} \text { b. peel }\end{array}$ & $\begin{array}{c}\text { Reactor D } \\
\mathbf{6 0 \%} \text { b. peel }\end{array}$ \\
\hline $\begin{array}{l}\text { Total biogas } \\
\text { generated (ml) }\end{array}$ & 22525 & 24795 & 32061 & 23151 \\
$\begin{array}{l}\text { Mean volume of gas } \\
\text { produced (ml/day) }\end{array}$ & 395.17 & 435 & 562.47 & 406.16 \\
\hline
\end{tabular}


Figure (5) shows the accumulation over 57 days, where the results indicated that there are big differences between the four reactors. Throughout the 57 days of retention time, reactor A achieved smallest quantity of gas $(\mathbf{2 2 5 2 5} \mathbf{~ m l})$ while reactor $\mathrm{C}$ achieved largest quantity of gas $(\mathbf{3 2 0 6 1} \mathrm{ml})$. Reactors $\mathrm{B}$ and $\mathrm{C}$ gave approximately equal quantity of gas.

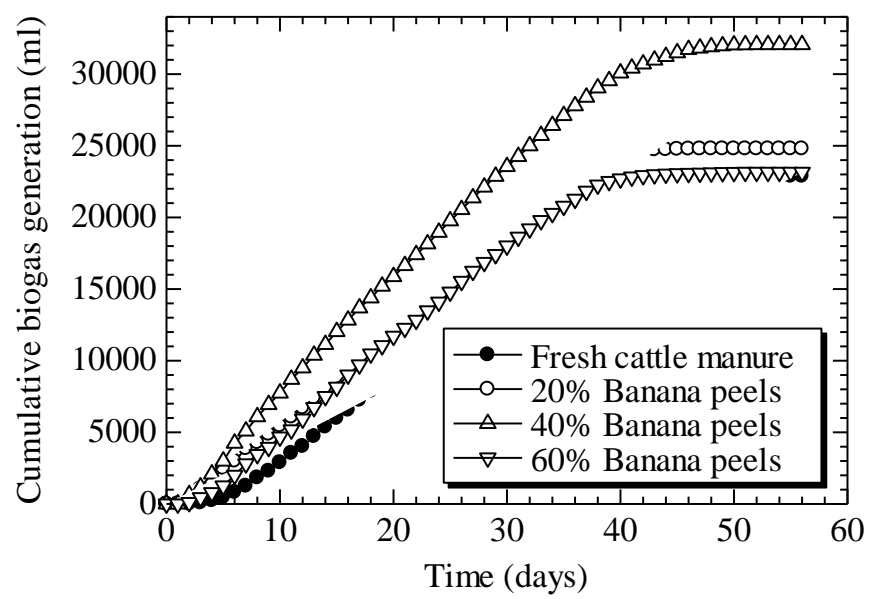

Fig. (5): Cumulative biogas generation

Figure 6. shows methane percentage versus retention time. Methane production from reactor $\mathrm{A}$ started on the $3^{\text {rd }}$ day and got to its peak on the $19^{\text {th }}$ day. Reactor B commenced methane production on the $3^{\text {rd }}$ day and got to its peak on the $16^{\text {th }}$ day. While reactor $\mathrm{C}$ commenced methane production on the $3^{\text {rd }}$ day and got to its peak on the $19^{\text {th }}$ day.

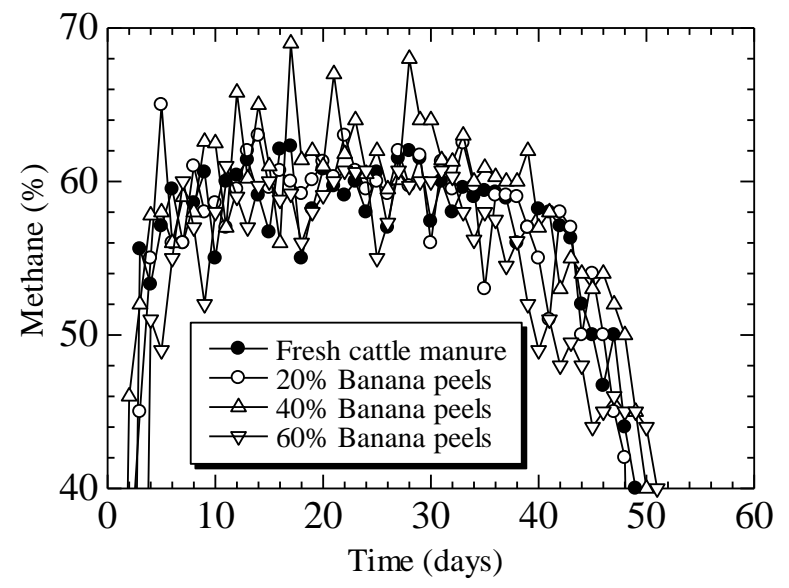

Fig. (6): Daily methane production 
While reactor $\mathrm{D}$ commenced methane production on the $5^{\text {th }}$ and got to its peak on the $13^{\text {th }}$ day. The difference in the lag time may be attributed to different commencement time of the activities of the methanogens.

Hence, reactor A with pure cattle manure gave average methane percent of $55.5 \%$. Reactor B with banana peels of $20 \%$ gave average methane percent of $57.1 \%$. The reactor $\mathrm{C}$ with banana peels of $40 \%$ gave average methane percent of $62.3 \%$. Reactor D with banana peels of $60 \%$ gave average methane percent of $56 \%$.

\section{CONCLUSIONS}

The main aim of this study is to make use of agricultural wastes such as banana peels in the production of biogas as a source of clean energy instead of discarded or burned, leading to contamination of the environment. This study has shown good results of gas production when using a mixing of $40 \%$ banana peels with cattle manure. The reactor $\mathrm{C}$ which has $40 \%$ banana peels gave the largest amount of gas compared with other reactors. In all reactors the gas started generation after 3-4 days due to the activity of the bacteria. Reactor A started the production on the $4^{\text {th }}$ day and retched to maximum value on the $29^{\text {th }}$ day $(800 \mathrm{ml} /$ day $)$ with average methane percent of $55.5 \%$. Reactor B started the production on the $3^{\text {rd }}$ day and retched to maximum value on the $6^{\text {th }}$ day $(870 \mathrm{ml} / \mathrm{day})$ with average methane percent of $57.1 \%$. Reactor $\mathrm{C}$ started the production on the $3^{\text {rd }}$ day and retched to maximum value on the $7^{\text {th }}$ day $(1250 \mathrm{ml} /$ day $)$ with average methane percent of $62.3 \%$. Reactor D started the production on the $4^{\text {th }}$ and retched to maximum value on the $17^{\text {th }}$ day $(850 \mathrm{ml} / \mathrm{day})$ with average methane percent of $56 \%$.

\section{REFFERENCES}

Anonymous, 1998. ASAE Standards. S269.4 Cubes, Pellets and Crumbles-Definitions and Methods for Determining Density, Durability and Moisture content ASAE DEC96. Standard S358.2 Moisture Measurement-forages. ASAE, St. Joseph, MI.

AOAC, 1990. Official Methods of Analysis. Association of Official Analytical Chemists, Washington DC, USA.

Badger, CM. Bogue MJ, Stewart DJ., 1979. Biogas production from crops and organic wastes. New Zeland Journal of Science, 22: pp. 11 20. 
Budiyono, I. N., S. J. Widiasa, and Sunarso, 2010. The Influence of Total Solid Contents on Biogas Yield from Cattle Manure Using Rumen Fluid Inoculum, International Journal of Engineering, Science Publications IJE TRANSACTIONS B: Applications Vol. 27, No. 2, pp. 177 184.

David J. Hills, David W. Roberts, 1981. Anaerobic digestion of dairy manure and field crop residues, Volume 3, Issue 3, July 1981, Pages 179 189.

Deublein, D. and A. Steinhauser 2008. Biogas from waste and renewable resources. Weinheim, Willey-VCH Verlag GmbH \& Co. KGaA.

Emmanuel E. S., A. M. Mshandete and A. K. Kivaisi, 2014. Biovalorization of Banana waste: Auditing and improvement of biomethane production by fungal pre-treatment, Journal of Chemical, Biological and Physical Sciences, An International Peer Review E-3 Journal of Sciences, Nov. 2013-Jan. 2014, Vol. 4, No. 1; pp. 818 833.

FAO, 1992. Biogas processes for sustainable development Uri Marchaim MIGAL Galilee Technological Centre Kiryat Shmona, Israel.

Garba, B., A. A. Zuru and A. S. Sambo, 1996. Effect of slurry concentration on biogas production from cattle dung. Nigerian Journal of Renewable Energy 4(2): pp. 38 43.

Hobson, P.N., 1983. The kinetics of anaerobic digestion of farm waste. J. Chem. technology biotechnology 33:1 20.

Khalid S. M., A. S. Fatma and M. B. Hassan, 2010. Banana-Growing tissue and its Impact on the Economic Return per Fedden in Egypt, Nature and Science, 2010-8(10), pp. 267 273.

Latika Bhatia, Sonia Johri and Rumana Ahmad, 2012. An economic and ecological perspective of ethanol production from renewable agro waste: a review, AMB Express, vol. 2, pp. 2 19.

Loehr, R. C., 1984. Pollution control for agriculture. (2nd edn), Academic Press, New York.

Maishanu S.M. and H.B.N. Hussani, 1991. Studies on factors affecting biogas generation from Pistia stratiote. The 32nd annual conference of Nigeria society for Microbiology, university of Ilorin, April, 711, 1991. 
Mohapatra D., S. Mishra and N. Sutar, 2010. Banana and its by-product utilization: an overview, J. sci. Ind. Res.; 69 (5), 323 329.

Muhammed T. K., M. Claudia, A. Dimitrios, B. Mathieu, M. Joachim, 2009. Anaerobic digestion of banana waste, a potential source of energy in Uganda, biophysical and socio-economic frame conditions for the sustainable management of natural resources. October 6-8, Hamburg.

NCAR, National Center for Atmospheric Research, Climate Research, Climates of the future; 2008.

NNFCC., (2011). National Non-Food Crops Centre. Renewable Fuels and Energy Factsheet: Anaerobic Digestion.

Ponsá S., I. Ferrer, F. Vázquez, X. Font, 2008. "Optimization of the hydrolytic-acidogenic anaerobic digestion stage $\left(55^{\circ} \mathrm{C}\right)$ of sewage sludge: Influence of $\mathrm{pH}$ and solid content." Water Res 42(14): 3972 3980.

Rashwan, M. A., H. A. Elsoury, A. I. A. Omara, 2013: Effect of total solids content on biogas production in a family scale biogas digester, Misr Journal of Agric. Eng., Vol. 30-No. (4) October 2013. pp.1195 1210.

Shaban D. Abou Hussein and M. S. Omaima, 2010. The Utilization of Agricultural Waste as One of the Environmental Issues in Egypt (A Case Study), Journal of Applied Sciences Research, 6(8): 1116 1124.

Tsunatu D. Yavini, I. Chia Azuaga, and A. John, 2014. Evaluation of the Effect of Total Solids Concentration on Biogas Yields of Agric. Wastes, Chemistry Dept., Taraba State University, P.M.B 1167, Jalingo - Taraba State, Available online at: www.isca.in, www.isca.me, Int. Research J. of Environment Sciences, ISSN 2319-1414 Vol. 3(2), 70 75.

Uzodinma, E.O. and A.U. Ofoefule, 2008. Effect of abattoir cow liquor waste on biogas yield of some agro industrial waste. Scientific Research and Essay, 3 (10): 473 478.

Veeken A, and B. Hamelers, 1999. Effect of temperature on hydrolysis rates of selected biowaste components. Biores Technol., 69:249254. 


\section{الملخص العربيى \\ تأثير خلط قثر الموز مع مخلفات الماشية على إنتاج الغاز الحيوى \\ *محد أبو الحمد عبد الحى رشوان}

يحتل الموز مركزاً كبير اً فى التجارة العالمية حيث يؤدى دوراً هاماً فى اقتصاد كثير من الدول بالإضافة إلى قيمته الغذائية العالية و إقبال المستهلك عليه أكثر من باقيى الفو اكه الأخرى الفى لما يتميز

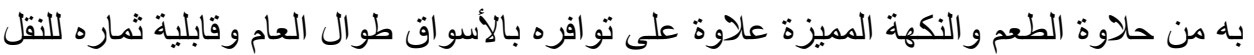

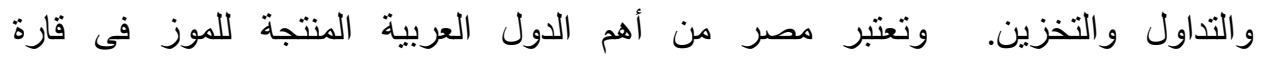

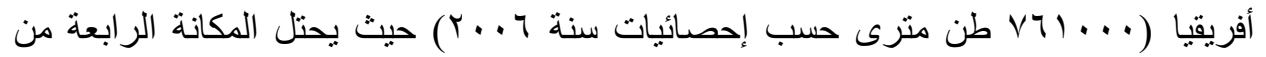

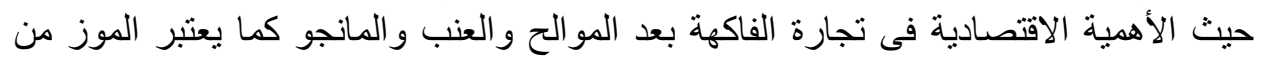

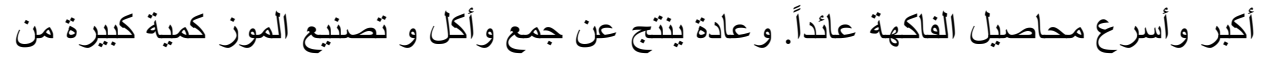
المخلفات و التى تسبب الروائح الكريهة نتيجة لتحللها مما يسبب تلوث البيئة ، غير أنها تعتبر غنية البها

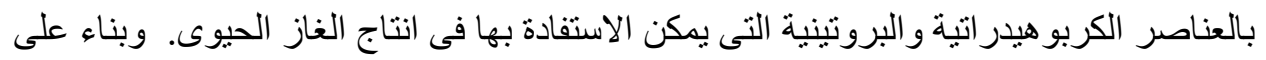

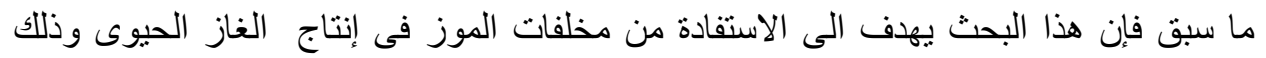
بدر اسة تأثير خلطها مع مخلفات الماثية بنسب مختلفة لمعرفة مدى تاثير ها على زيادة كمية الغاز

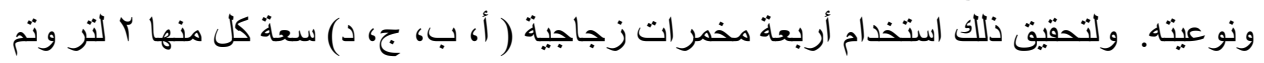
وضع وخلط المكونات بالنسب الآتيه:-

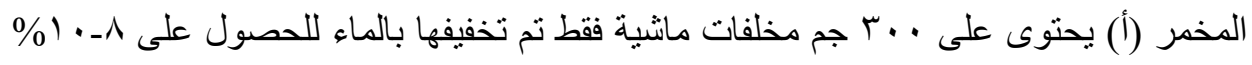

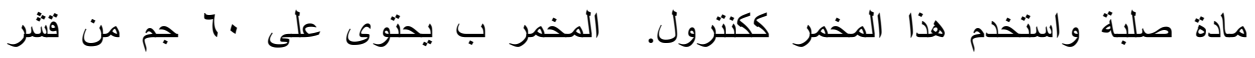

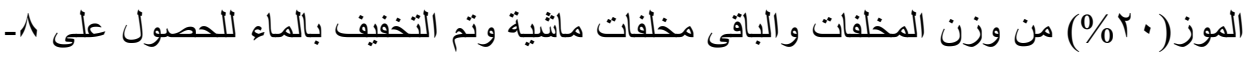

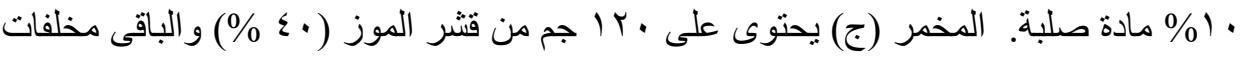

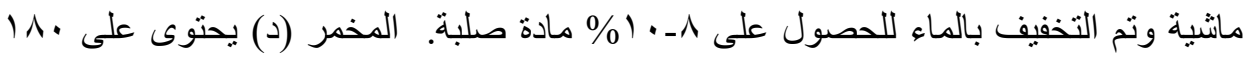

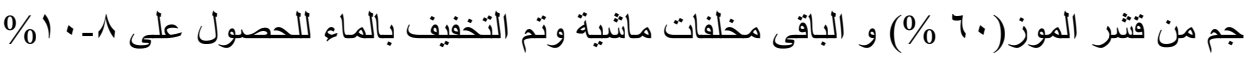
مادة صلبة. وقد تم وضع المخمر ات الاربعة داخل حمام مائى درجة حر ارته هب دم درجة مئوية

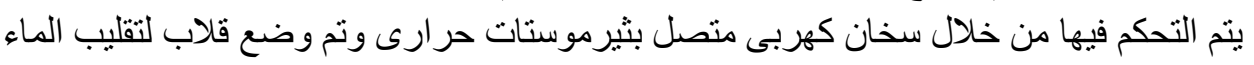

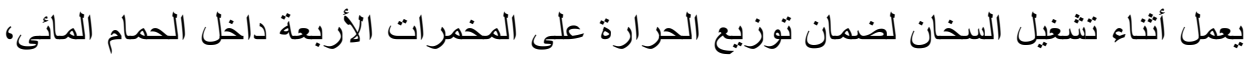

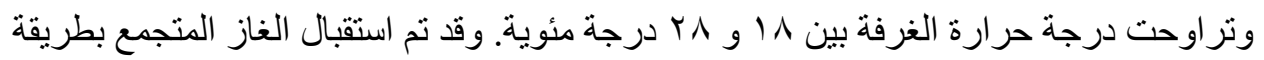

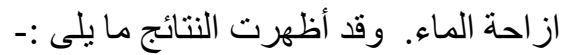
إضافة قشور الموز الى المخلفات الحيو انية أدى الى زيادة واضحة فى كمية الغاز الناتج مقارنة

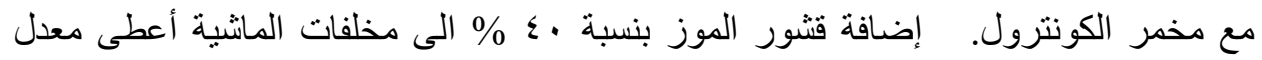

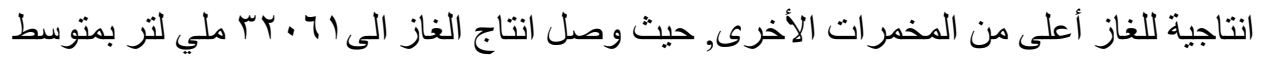

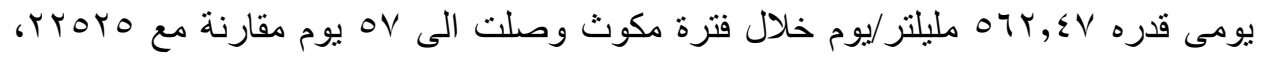

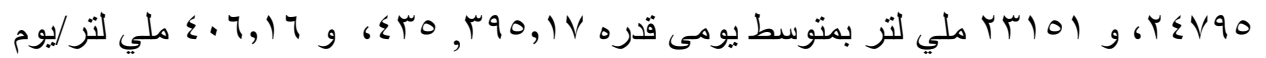

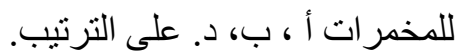

*مدرس بقسم الهندسة الزراعية والنظم الحيوية ـ كلية الزراعة - جامعة الاسكندرية - جمهورية مصر العربية. 